\title{
Teaching undergraduate nursing in mental health as allied to the consolidation of the Psychiatric Reform movement
}

\author{
Ensino de graduação em enfermagem em saúde mental como aliado à consolidação do movimento \\ de Reforma Psiquiátrica

\section{Enseñanza de graduación en enfermería en salud mental como aliado a la consolidación del movimiento de Reforma Psiquiátrica}

\begin{abstract}
Gizele da Conceição Soares Martins ${ }^{1}$ (it Maria Angélica de Almeida Peres ${ }^{2}$ (iD) Tânia Cristina Franco Santos ${ }^{2}$ (D) Paulo Joaquim Pina Queirós ${ }^{3}$ (iD Carolina Fraga Paiva ${ }^{2}$ (iD
\end{abstract} Antonio José de Almeida Filho ${ }^{2}$ (iD)

1. Universidade Federal do Rio de Janeiro. Macaé, RJ, Brasil.

2. Universidade Federal do Rio de Janeiro. Rio de Janeiro, RJ, Brasil.

3. Escola Superior de Enfermagem de Coimbra. Coimbra, Portugal.
Corresponding author:

Gizele da Conceição Soares Martins. E-mail: gizelemartins16@hotmail.com

Submitted on $06 / 07 / 2018$.

Accepted on 08/28/2018.

DOI: 10.1590/2177-9465-EAN-2018-0164

\begin{abstract}
Objective: To analyze the updating of mental health education in a Nursing Undergraduate Course concomitantly with the implementation of the Psychiatric Reform in the municipality of Volta Redonda. Method:Historical-social study with primary sources consisting of written and oral documents. The analysis, based on the main concepts of the Psychiatric Reform, was performed by the triangulation of data. Results: In a transitional phase of mental health models, the municipality studied developed strategies to develop psychiatric reform, of which the creation of CAPS stands out. At the same time, an agreement with the Undergraduate Nursing Course enrolled students, still in the 1990s, in all the mental health services of the municipality. The teachers of this course acted as nurses, one in care and another in mental health management, facilitating the teaching-assistance dialogue. Conclusion: The graduate students, to integrate as interns services, contributed to the change of the concepts that supported the mental healthcare, while the psychiatric reform developed. This was a successful strategy to stimulate the formation of a new logic and care to brings killed labor to services, since the course graduates opted for acting in CAPS.
\end{abstract}

Keywords: History of Nursing; Psychiatric Nursing; Teaching.

\section{Resumo}

Objetivo: Analisar a atualização do ensino de saúde mental em um Curso de Graduação em Enfermagem, concomitantemente à implantação da Reforma Psiquiátrica no município de Volta Redonda. Método: Estudo histórico-social com fontes primárias constituídas de documentos escritos e orais. A análise, sustentada nos principais conceitos da Reforma Psiquiátrica, foi realizada pela triangulação de dados. Resultados: Em uma fase de transição de modelos de saúde mental, o município estudado criou estratégias para desenvolver a Reforma Psiquiátrica, das quais se destaca a criação dos Centros de Atenção Psicossocia (CAPS). Ao mesmo tempo, um convênio com o Curso de Graduação em Enfermagem inseriu estudantes, ainda na década de 1990, em todos os serviços de saúde mental do município. As professoras desse curso atuavam como enfermeiras, uma na assistência e outra na gestão em saúde mental, facilitando o diálogo ensino-assistência. Conclusão: Os estudantes de graduação, ao se integrarem nos serviços como estagiários, contribuíam para a mudança dos conceitos que sustentavam o cuidado em saúde mental, enquanto a Reforma Psiquiátrica se desenvolvia. Esse fato foi uma estratégia bem-sucedida para estimular a formação segundo uma nova lógica assistencial e trazer mão de obra qualificada aos serviços, uma vez que egressos do curso optaram pela atuação nos CAPS.

Palavras-chave: História da Enfermagem; Enfermagem Psiquiátrica; Ensino.

\section{REsumen}

Objetivo: Analizar la actualización de la enseñanza de salud mental en un Curso de Graduación en Enfermería concomitantemente a la implantación de la Reforma Psiquiátrica en el municipio de Volta Redonda. Método: Estudio histórico-social con fuentes primarias constituidas de documentos escritos y orales. El análisis, sostenido en los principales conceptos de la Reforma Psiquiátrica, fue realizado por la triangulación de datos. Resultados: En una fase de transición de modelos de salud mental el municipio estudiado creó estrategias para desarrollar la reforma psiquiátrica, de las cuales se destaca la creación de los CAPS. Al mismo tiempo, un convenio con el Curso de Graduación en Enfermería insertó a estudiantes, aún en la década de 1990, en todos los servicios de salud mental del municipio. Las profesoras de ese curso actuaban como enfermeras, una en la asistencia y otra en la gestión en salud mental, facilitando el diálogo enseñanza-asistencia. Conclusión: Los estudiantes de graduación, al integrar como pasantes los servicios, contribuían al cambio de los conceptos que sostenían el cuidado en salud mental, mientras la reforma psiquiátrica se desarrollaba. Este hecho fue una estrategia exitosa para estimular la formación en una nueva lógica asistencial y para traer mano de obra calificada a los servicios, una vez que los egresados del curso optar por la actuación en los CAPS

Palabras clave: Historia de la Enfermería; Enfermería Psiquiátrica; Enseñanza. 


\section{INTRODUCTION}

Teaching and internships in Psychiatric Nursing have been mandatory in Nursing education in Brazil since 1949, when Law $775 / 49^{1}$ was enacted. Despite the introduction of Nursing theories in undergraduate Nursing courses, as of the 1960s, Psychiatric Nursing theories were not mostly applied in practice, following the established principles of psychiatric hospital care, which often worked without the presence of nurses.

Keeping up with Psychiatric practice, teaching, until the 1980s, was based on the biomedical model, focused on psychopathologies and treatment that prioritized the incarceration of people with mental disorders in long-term institutions. Thus, the theoretical and practical training of Nursing was given, as a matter of priority, in a supervised internship in the mental institutions, reinforcing the understanding that care had as its foundation maintaining the lives of hospitalized people, focusing on medication, food and hygiene. ${ }^{2}$

Still in the 1980s, the Psychiatric Reform movement began to take shape, in which discussions about the biomedical paradigm, which supported Psychiatry in mental institutions, were openly questioned as for their effectiveness. Since that historical moment, there have been many changes in public health policies - most importantly, the creation of the Unified Health System (SUS), as a health model for the country - that brought a new conception of Health, with the center being users of services, called for citizen participation in the management of Health Care at different levels. This participatory logic was to meet the Psychiatric reform movement, opening spaces for changes in mental health practices and policies, with direct implications for Nursing, once it should move towards acting to substitute mental institutions, such as the Centers for Psychosocial Care (Centros de Atenção Psicossocial - CAPS). ${ }^{3,4}$

The Brazilian Psychiatric Reform movement had its culmination with the National Mental Health Policy (Política Nacional de Saúde Mental - PNSM), approved with the enactment of Law 10.216/01, which, along with other Regulations of the Ministry of Health approved in the 1990s, reoriented care for a territorially based model, with a view to overcoming the hegemony of the mental institutions model. ${ }^{4,5}$

In 2001, in the same year of the PNSM approval, CNE/ SES Resolution No. 3/01 established the National Curricular Guidelines (Diretrizes Curriculares Nacionais - DCN) of the Undergraduate Nursing Course. Therefore, it happened in the context of changing public policies in Mental Health. Thus, public and private higher education institutions were expected to link Mental Health/Psychiatry disciplines to collective health and community care, according to the SUS prerogative. ${ }^{6,7}$

The new care model created expectations for undergraduate Nursing education in mental health. The perspective was that it would accompany such changes, leading to the necessary changes to account for the paradigmatic transition from the biomedical model to the psychosocial care model that was now in place. Thus, the focus of the teaching process had to also consider Nursing care in community-based services, for which new forms of care would be built, based on the guidelines of the SUS and the functioning of CAPS. ${ }^{5,6}$

There were, however, some obstacles to the theoretical teaching and Nursing internship in mental health from the point of view of the Psychiatric Reform, regarding pedagogical practice. ${ }^{2,5}$ Many professors reproduced, in mental health teaching, the model of care still based in practices of containment of the behavior of people in psychological suffering, which is medicalizing and excluding.

Faced with a transformation such as that initiated with the implementation of the Psychiatric Reform, the lack of faculty training implied the absence of a theoretical-scientific and historical-political framework that inhibited the critical and reflexive potential of these professors in Mental Health to train nurses, towards psychosocial attention.

As of 2001, the national guidelines for teaching the practice of mental health care advocated that it should occur, preferably, in extra-hospital services, such as the CAPS. Therefore, in municipalities that had mental institutions and CAPS, the recommendation was that only technical visits be made with students to these places. In municipalities that only had mental institutions, the recommendation was try not to reproduce technical and bureaucratic practices, that is, there was an incentive to change pedagogical practices, even in mental institutions, where the supervisor would teach nursing care based on the principles of the Psychiatric Reform. 2,4,6

However, it should be considered that in the first years of implementation of substitutive models of Mental Health Care in many municipalities, such as Volta Redonda, located in the south of Rio de Janeiro State, the mental institution still existed as the main place of care and, the CAPS created were insufficient to absorb the population with mental disorders. In the same municipality, there were conflicting proposals for care, given that the peculiarities of each municipality should be considered to prevent the lack of care to the institutionalized people, most of whom would not have anywhere to go if mental institutions were to be closed, without designating a place of housing and assistance for them. ${ }^{3,6}$

The municipality of Volta Redonda had, in 1999, three care services for adults with mental disorders. At that moment, it was constituted as follows: the Health House Volta Redonda (Casa de Saúde Volta Redonda - CSVR), which was a health institution under municipal intervention, where the Center for Mental Health Studies (Centro de Estudos em Saúde Mental - CESAM) was located; and the Centers of Psychosocial Attention (Centros de Atenção Psicossocial - CAPS) Usina de Sonhos, created in 1995, and Vila Esperança, created in 1999. 
An agreement started in 1995 between the CESAM and the Barramansense Association of Education (Associação Barramansense de Ensino - SOBEU) was established so that the practical teaching of undergraduate Nursing in the discipline of Mental Health occurred in these devices.

Thus, this study has as a guiding question: how did undergraduate Nursing education in mental health manage to follow the guidelines of the Psychiatric Reform movement in Volta Redonda, considering the presence of two care models in the same municipality? And, as objective: to analyze the updating of mental health education in a Nursing Undergraduate Course concomitantly with the implementation of the Psychiatric Reform in the municipality of Volta Redonda.

\section{METHOD}

Qualitative, descriptive and exploratory research, with historical-social approach. Social history can be used by Nursing insofar as it provides support to investigate past phenomena that involve collective actors inserted in a social-dynamics. ${ }^{8}$ It was considered the perspective of the history of the present time, in which the object researched meets the contemporary demand and the researcher is temporarily close to the phenomenon studied. ${ }^{9}$

The time cut-off covers the years 1995 to 2000 , starting in the year in which CESAM's agreement with SOBEU took place, and ending in the year of inclusion of former students of SOBEU as nurses in the mental health services of Volta Redonda municipality. The relation between the initial and final frame of the time period is in the fact that the nurses who, during undergraduation, had internships in mental health services, returned to them to practice their professional practice.

Data collection was performed from October to December 2015. The primary sources used were documents found at the Municipal Health Department of Volta Redonda (Secretaria Municipal de Saúde de Volta Redonda), such as: agreements, minutes of meetings, service planning, among others; and in the personal collection of one of research participants, such as: teaching plan and internship schedule. Other primary sources were interviews with six participants who met the following inclusion criteria: having taught theoretical and practicaltheoretical mental health content in SOBEU for undergraduate Nursing students and being a former student of this Course, in the time cut-off of research. As secondary sources, articles and books on the subject under study were used.

The interviews were carried out in places defined by the interviewees, individually, according to the thematic oral history technique. ${ }^{8} \mathrm{~A}$ semi-structured interview script and a cellular device were used, with an audio recording application. After completion, the interviews were transcribed, and the texts delivered to the participants to be validated. In this process, the participant is invited to check and indicate changes in the text, if he/she wishes.
After validation, the interviews became the documentary corpus of the study with the other sources. Data processing occurred by reading the sources, thematic selection and chronological grouping of events. The analysis was based on the triangulation of data based on the internationally known concepts of deinstitutionalization and psychosocial rehabilitation that guide the Psychiatric Reform.

This study was approved by the Research Ethics Committee on 04/29/2015 and followed the Resolution of the National Health Council (Resolução do Conselho Nacional de Saúde) No. 466/12, which deals with research with human beings.

\section{RESULTS}

Mental health policy in Volta Redonda had been under development since the municipal intervention in the CSVR in 1994. At that time, there were municipal government powers to train workers and managers through a partnership between CESAM and the Franco Basaglia Institute (Instituto Franco Basaglia - IFB), which provided consulting and legal advice to professionals, about their role in the transition from the traditional psychiatry model to the territorial base model, because there were few people who knew about the Psychiatric Reform movement in Brazil. Such an effort was in line with the national scenario of the era of development and redirection of care in mental health.

From 1995 onwards, the role of Nursing assistants in the Mental Health field in the city of Volta Redonda started to be articulated with the professional training process of nurses from SOBEU, becoming a place for the development of theoretical classes in Nursing in mental health, being the CAPS Usina de Sonhos the supervised internship scenario.

In Volta Redonda, in 1998, the regionalization by territory was subdivided: Regionals I, II, III, and IV, being later changed to Sanitary Districts (SD). This proposal of division in Sanitary Districts was in line with the proposal of decentralization, as recommended by SUS. Thus, the population began to have their demands received in areas attended by Volta Redonda. ${ }^{10}$

The management of the Sanitary District II (SDII), had a nurse of great expression in the municipality because she could dialogue with the teaching in the Undergraduate Nursing Course of SOBEU and with the State Department of Health (Secretaria Estadual de Saúde), in the management of services of the municipal collective health network, still incipient at the time.

A fact considered representative of this study, involving Nursing of Volta de Redonda was that the nurse manager of District Il was also president of the Brazilian Association of Nursing (Associação Brasileira de Enfermagem - ABEn) - Regional Volta Redonda, in the management of 2001-2004, whose motto was "With no Participation there is no Association". The regional ABEn of Volta Redonda attended 14 nearby municipalities that did not have nucleus of this Association, as it appears in the Document of $A B E n$ - Regional Volta Redonda Management 2001-2004. 
In the excerpt from the interview of a former student of SOBEU about the training process, it is noted that she considered education in line with mental health policies at national and local levels:

She [nurse/professor] had a movement that was already very different from the faculty of the institution. She was also very politically involved with the Psychiatric Reform movement at the time she was a city hall's professional. Then she had been bringing news, and it drove us really amazed. (NUR2)

The nurse, who worked in the teaching and management of the SDII, was aligned with changes in national and municipal health policies and, once the CAPS Usina de Sonhos was inaugurated, the students began to supervise this unit.

The internships of SOBEU Nursing students in 1997 were carried out at the two mental health centers of Volta Redonda, Casa de Saúde Volta Redonda, still under intervention, and CAPS Usina de Sonhos. It is worth mentioning that, as the municipality created extra-hospital care spaces, the theoreticalpractical mental health education of the undergraduate students in Nursing at SOBEU was inserted in these spaces, to provide an experience compatible with advances in the field of mental health:

We went to CAPS as students, we had opportunity to go to mental institutions, we spent a short period there, as students under internship. CAPS was inaugurated and then we went to train there, went through the workshop, and interacted in the team discussions. (NUR2)

So we started the internship at CAPS, but we had moments that we were going to the Psychiatric Hospital, which was the Health House [CSVR] at the time, even to experience what it was like inside a hospital, but the internship was basically in CAPS. (NUR3)

In order to offer a theoretical-practical contribution to subsidize the students' training, classes were taught with methodologies aimed at the collective construction of knowledge, involving the student of the Undergraduate Nursing Course, through discussions, debates and lectures. Some of the resources used were legislation proceeding in the National Congress, as well as Ministerial Ordinances already approved, such as those related to the Psychiatric Reform movement.

We discussed the project that originated Law 10.216, the discussions we had at the congress to approve, or not, having Pedro [Delgado] as our coordinator. I remember that there was a lesson, whose dynamics was for us to suggest what we understood that should be in the legislation. So, this is what happened, it was interesting knowing we could be part of this process during undergraduation. (NUR3)

The internship of undergraduate students of SOBEU undergraduate course was made possible by a partnership between the Center for Mental Health Studies (Centro de Estudos de Saúde Mental - CESAM) of Casa de Saúde Volta Redonda (CSVR) and SOBEU, through a document entitled: Organization of the Internship in Nursing/SOBEU in Mental Health, dated from 1997. This document records the importance of ensuring the reception of Nursing students, as it was expressed the need to clarify them regarding the activities and composition of the care team in both services. ${ }^{11}$

The protocol to develop the internship explained the need for the presence of a supervising professor in the field: "It will not be up to the professionals of reference to offer supervision to the trainees. It is a responsibility of the training institution."11:3

There were expectations about how the internship could still contribute to the users of Volta Redonda's mental health services, as well as provoke reflection on the stigma towards the person in psychic suffering and the know-how characteristic of traditional psychiatry, being the certainties questioned:

Madness is an experience that presents itself in the social imagery invariably associated with danger and exclusion. We hope, during this internship, to raise some questions about these 'certainties' and to make the contact of the professional in formation with people suffering from psychic suffering and with the organized assistance mechanisms in order to guarantee the reception necessary (or at least possible) to them. ${ }^{11}$

The relationship of CAPS Usina de Sonhos team with the trainees was good and with effective participation of a supervising professor, as reported by the service staff:

We dealt well with this [presence of the trainee], there was no problem, from the very beginning we had a trainee there. The [professor/nurse] was always following [...]. So we would have a meeting with this mini-team to discuss the cases and see what the conduct would be, from which we would draw the therapeutic project, that whole business. And, there was always a trainee who was together. (ASS)

The [nurse/professor] came with a student here. Even though she was not in [being an employee] of the CAPS, she knew everything, she knew a lot about mental health. (ADM) 
[nurse/professor] she was an important person in this, she was a professor as well as another SOBEU professor, and they started to introduce the public health issues of the Psychiatric Reform into the Nursing course and began to do internships there. (PSY)

Starting in 2000, CAPS Vila Esperança also started to count on students from the Undergraduate Nursing Course at $S O B E U$, and the professor was also the nurse of this CAPS. This professional had also been invited to participate as a Nursing Coordinator at the time of the municipal intervention in the CSVR.

For this teaching nurse of the Undergraduate Nursing Course, teaching should be based on the absence of labeling, stigma and prejudice related to mental illness, in addition to seeking full care:

What I emphasized most is that the individual could have a normal life as a diabetic, such as a hypertensive patient, who are chronic pathologies that could coexist with chronic pathology but, unfortunately, were in that condition [hospitalized] due to lack of competence and capacity of municipality, state and federal government levels. (NUR1)

It is important to highlight the updated perspective of both the professionals who made up CAPS and the Center for Mental Health Studies, recognizing that there was stigma among health professionals to care for people with mental disorders and, in Nursing trainees, they had human resources with the potential to decrease negative effects on care.

At CAPS Vila Esperança, the student who was supervised by the professor, who was also a care nurse, was seen with a certain expectation of enabling care changes and as an opportunity to generate reflections in the team and individually:

I used to say this, that we also chronify in spaces, I really like students, I even talked to them: you make me think things must progress. It's young people, they're new people with another look and I've always said that. On the first day of internship I would say: you are here not to think what we think. (NUR1)

Through the supervised Nursing Undergraduate Course, mental health knowledge remained active, because professionals had the opportunity to update themselves, both in an active way by the presence of Nursing students, as well as by participation in the teaching and learning process.

Entering the devices that provided direct relation to the training and qualification of professionals, it can be considered that two poles were constructors and diffusers of knowledge: CSVR, with CESAM; and SOBEU, with the Undergraduate Course in Nursing.
Even though students had the opportunity to be in the mental health field in mental institutions, the teaching proposal used by professors did not include traditional psychiatry and was not restricted to the disease. Therefore, it was a proposal to have contact with the local reality - CSVR - without, however, reproducing completely the mental institution logic. The incorporation of the principles of the Psychiatric Reform during professional formation made the performance of a former student difficult, in a health institution when hired as a Nurse:

I had a consolidated current training in relation to the Psychiatric Reform. The formation of my class was very different. And then when I went to work in the psychiatric hospital I saw that it had nothing to do with what I had studied, I said, my God, or I studied everything wrong or this is unusual here. I was able to implement some changes within this hospital, through the persuasion of professionals, because through knowledge it was impossible, they were professionals of thirty years in the service. We started hiring new professionals, but it was very difficult, and I could not handle it, and my strategy was to escape, it was to leave the hospital. (NUR3)

Later, in 2000, a newly formed student was working at the CAPS Usina de Sonhos, where she was a trainee during the undergraduate course and was professionally identified:

I already worked in a psychiatric hospital, but not in the municipality of Volta Redonda. So I left that city where I worked and came to Volta Redonda to be able to work specifically with CAPS. [...] I joined in July 2000. So when I joined I already had a reasonable structure, CAPS already existed a few years ago, I joined the CAPS Power Plant and the job of the nurses basically was the care with these people within a multidisciplinary process. (NUR3)

Also in 2000, another former student also joined the institution to work as a nurse at CAPS Usina de Sonhos:

When I entered CAPS I questioned myself a lot. Even though I had a lot of interest, in the first few days I kept wondering all the time: What would I do as a nurse there? [...] and then I began to remember that the professor had given a therapeutic environment lesson and therapeutic relationship and I was putting it into practice. It was great [...]. (NUR1)

Given the reports of former female students, during the study period, it was noted that there was an insecurity probably due to the lack of contact with the subjective tools in other disciplines taught during the Nursing Undergraduate Course. In addition, 
it is important to consider that this was a transitional phase, in which teaching was not based on bureaucratic, prescriptive and protocol care, in force at the time, and the undergraduate student had not yet reached the level of decision-making with initiative and creativity.

Therefore, it is worth highlighting the fact that these nurses interviewed were part of the first group of trainees of the Undergraduate Nursing Course of SOBEU to join CAPS Usina de Sonhos, having access to the assistance model based on biopsychosocial, based on the perspective of the Psychiatric Reform, with only occasional visits to the CSVR. And, in their report, it is evident how the Nursing discipline in mental health, at that moment, positively influenced the career and the choice of the field of action as nurses and the development of the Psychiatric Reform in the municipality.

\section{DISCUSSION}

A study carried out in the state of Santa Catarina ${ }^{5}$ and another in that of Mato Grosso ${ }^{12}$ pointed out that,the focus of Nursing education in mental health in the oldest universities in the state was still based, in 2010, on psychopathology and on medical diagnoses, without coherence with psychosocial care, with the Psychiatric Reform and SUS. In this sense, in view of the results presented, the municipality of Volta Redonda, through $S O B E U$ and the partnership with CAPS, had an updated position on Nursing Education in mental health, still in the 1990s.

This fact differs from the reality of other Brazilian municipalities studied, given that effective strategies for teaching Nursing in mental health, compatible with the psychosocial model are still discussed today. Despite the field of Mental Health, in the time cut-off of the study, being under construction, in view of the paradigmatic transition from the biomedical model to the psychosocial care, other studies pointed out that there are contradictions between what was advocated and what was developed in the student training process. ${ }^{5,6,12}$

The CESAM inauguration initiative, in 1994, focused on issues related to demands of the Psychiatric Reform, seeking improvements and transformations of human resources for care at hospital and extra-hospital levels, and this strategy includes open access to the academic community. ${ }^{13}$

The hiring of the Franco Basaglia Institute can be considered an important initiative to enable professionals to act accordingly to the Psychiatric Reform. Mainly due to the influence that Franco Basaglia had, through his achievements in Italy and his visits to Brazil, in which he directed mental health care and encouraged the creation of CAPS in Brazil. ${ }^{14}$

The influence of the nurse and professor of SOBEU should be considered a relevant fact. She supervised the undergraduate Nursing students in the nonpartisan political context of Volta Redonda, as professor, as president of $A B E n$ and manager of Sanitary District II, where CAPS Usinha de Sonhos was in. ${ }^{15}$
ABEn is considered a heritage of Brazilian Nursing, that acts through its sections and regions. It is considered a non-profit private association of public interest, with partnerships established between several national and international bodies, which contributes to Nursing education at different levels in the country. ${ }^{15}$

This double linking - nurse and professor - also responsible for the internship at CAPS Vila Esperança contributed to the development of the Psychiatric Reform in the municipality, since professors knew the needs and difficulties of the municipality and its users. Thus, they could direct students to experience nursing care for these demands in psychosocial logic. These initiatives were in accordance with what is recommended by the $D N C$.,10,16

In 1997, at SOBEU, the configuration of the scenarios of supervised Nursing internships in mental health, prioritized the experience of care in CAPS, with technical visits in the CSVR, directing the training of new professionals to the aspirations of the Psychiatric Reform. Hence, as pointed out in another study, without abandoning the reality of hospitalization, which although still present in the municipality, should not be the main resource of care in training new nurses. ${ }^{6}$

Faced with this, in the municipality of Volta Redonda, changes in Mental Health Care, starting with the creation of CAPS, approached what was presumed at the time as desirable care for the Psychiatric Reform. These changes were immediately shared with undergraduate Nursing education through the supervised student placement in CAPS. In addition, corroborating with other studies, students of Nursing were trained from a biopsychosocial perspective, without, however, neglecting the reality of mental health services of the municipality that still had a psychiatric hospital - CSVR. 2,4,6,16

This view of mental health teaching, applied by both teaching nurses responsible for the undergraduate students' training in the two CAPS, deserves to be highlighted, as they provided, in due time, a dialogue with the discussions about redirecting the health care model in mental health at the time of its development, both by the II National Conference on Mental Health (II Conferência Nacional de Saúde Mental), and by the Ministry of Health Ordinances; and even before Law 10.216/01 was sanctioned. ${ }^{3}$

Thus, even before the approval of the National Curricular Guidelines for the Nursing Undergraduate Course (DCN/ENF) in 2001, the professors of SOBEU had already adopted the pedagogical principle, as foreseen in $D C N / E N F$, regarding the skills and abilities necessary for the formation of future generalist nurses, able to act in mental health, with unfocused attention of the disease, ${ }^{16,17}$ considering the importance of the reception, therapeutic relationship, active listening, therapeutic groups and workshops, as care tools of the mental health nurse. ${ }^{18}$

It is worth highlighting that the student's approach to the new care model in mental health services was also seen as comfortable and positive according to a study carried out in Sweden. ${ }^{19}$ In addition to this positive view, interdisciplinary exchange, through the multiprofessional team, is important for 
the teaching-learning process of students in mental health to provide quality care, in addition to being in line with the proposal of the $D C N$ of 2001 , mainly with the provision in its Article $14.6,19$

As far as stigmatization is concerned, a study conducted in the United States showed that the inclusion of students in services made the prejudice lessened and the availability for care free of pre-judgments increased. ${ }^{19}$ In addition, it was verified that, with the presence of students cases were more discussed, care was planned in a more holistic way and new possibilities were sought to cope with problems of daily service. These attitudes served as incentives for older nurses in the mental health service to develop other possibilities of care, mainly focused on therapeutic relationship and communication. ${ }^{18,19}$

This finding is consistent with the reality of Volta Redonda, in which the integration of teaching - university - and work (CAPS) was understood as beneficial for all those involved, since it required a practice consistent with the proposal of a CAPS and critical and reflective thinking for quality, non-fragmented Mental Health Care.

In addition, other national and international studies have evidenced variables that have a decisive influence on the choice of Nursing undergraduate allocation in the labor market, such as: theoretical contribution; teaching support; approximation with users of the services with the possibility of providing assistance; the interaction between the service team; and the coherence between the ideal to be practiced and the reality found in practice. .,18-21 $^{1}$

A study carried out in the United Kingdom and Australia, pointed out that the choice of Nursing undergraduate students for mental health can be directly related with the experiences of care promoted during undergraduation, that is, still as trainees. ${ }^{22}$ Thus, this study points out that, in Brazil, the same affirmative is applied based on research presented in this article.

\section{CONCLUSION}

This study records the development of the Psychiatric Reform in Brazil, linking undergraduate Nursing education and updating of mental health practices in a municipality in the southeast region of the country. Faced with the reformulation of public policies to reorganize Mental Health Care in this municipality, a teaching institution, for having municipal nurses integrating these services, was a pioneer in inserting students into CAPS and reducing their permanence in mental institutions, although it did not leave aside this place as a field of practice, in which the logic of care focused on deinstitutionalization was used.

Thus, professors and nurses who worked in CAPS and in the management of basic care of the municipality of Volta Redonda were directly involved in this, so that it served as an example to train nurses sensitive to a new model of Nursing care to people under psychic suffering, through $S O B E U$, a private higher education institution in the region.
It can be affirmed that such nurses, acting as professors, were part of an engaged group, with knowledge about the Psychiatric Reform at national and local levels, and about the political-assistance circumstances that involved this movement. This allowed these nurses-professors to contribute to teaching and disseminating the guidelines of the Brazilian Psychiatric Reform movement, both in theory and in the practice of care, education and management.

Thus, the dynamics of knowledge flow was in the direction of biopsychosocial attention since there were changes and significant contributions made by nurses, together with the professionals of the interdisciplinary team of CAPS and undergraduate students in Nursing.

Thus, this study contributed to evidence that Nursing influenced the movement of the municipal Psychiatric Reform. This movement also had a direct influence on the teaching of Nursing in mental health, since there was a return of nurses trained according to this perspective in Volta Redonda, to work in the CAPS of the municipality.

Therefore, the updating of mental health education in the Undergraduate Course in Nursing of SOBEU occurred at the same time of the implementation of the Psychiatric Reform in Volta Redonda, still in the 1990s. The way in which the theoretical and practical teaching of Mental Health/Psychiatric Nursing in Volta Redonda occurred was at the forefront of future guidelines of the 2001 National Curricular Guidelines for Nursing, even before its publication. Considering that some educational institutions in Brazil, in 2010, still had difficulties to base teaching on the psychosocial care model, it could be said that in Volta Redonda there was a successful model in teaching Nursing in Mental Health, in the time cut-off of research.

\section{REFERENCES}

1. Carvalho MS, Martins GCS, Dias NL, Santos TCF, Almeida Filho AJ Peres MAA. O ensino de enfermagem psiquiátrica na Escola Ana Néri, na primeira metade do século XX. Rev Eletr Enferm [Internet]. 2015 Jan/Mar; [cited 2017 Nov 2]; 17(1):85-93. Available from: https://doi org/10.5216/ree.v17i1.23546

2. Kantorski LP. A brief history of psychiatric nursing teaching in Brazil Nurse Educ Pract [Internet]. 2005 Jan; [cited 2017 Nov 1]; 5(1):58-60. Available from: http://www.nurseeducationinpractice.com/article/S14715953(04)00099-X/pdf

3. Ministério da Saúde (BR). Secretaria-Executiva. Secretaria de Atenção à Saúde. Legislação em saúde mental: 1990-2004. Brasília (DF) Ministério da Saúde; 2004.

4. Maftum AM, Silva AG, Borba LO, Brusamarello T, Czarnobay J. Mudanças ocorridas na prática profissional na área da saúde mental frente à reforma psiquiátrica brasileira na visão da equipe de enfermagem. J Res Fundam Care Online [Internet]. 2017 Apr/ Jun; [cited 13 Aug 2017]; 9(2):309-14. Available from: http://dx.doi. org/10.9789/2175-5361.2017.v9i2.309-314

5. Rodrigues J, Santos SMA, Spricigo JS. Ensino do cuidado de enfermagem em saúde mental através do discurso docente. Texto Contexto Enferm [Internet]. 2012 Sep; [cited 2017 Nov 1];21(3):616-24. Available from: http://dx.doi.org/10.1590/S0104-07072012000300017 
6. Rodrigues J, Santos SMA, Zeferino MT, Tosoli M. Integrative review about the teaching of the nursing care in mental health. J Res Fundam Care Online [Internet]. 2014 Jan/Mar; [cited 2017 Nov 2]; 6(1):433-49. Available from: http://www.seer.unirio.br/index.php/ cuidadofundamental/article/view/2650

7. Fernandes JD, Rebouças LC. Uma década de Diretrizes Curriculares Nacionais para a Graduação em Enfermagem: avanços e desafios. Rev Bras Enferm [Internet]. 2013 Sep; [cited 2017 Nov 8]; 66(no. spe):95-101. Available from: http://dx.doi.org/10.1590/S003471672013000700013

8. Ferreira A, Canastra A, Esteves A. Investigação em história de enfermagem: um contributo do passado para o futuro. Rev Enferm Ref [Internet]. 2013 Dec; [cited 2017 Nov 8]; serllI(11):153-8. Available from: http://www.scielo.mec.pt/scielo.php?script=sci_arttext\&pid =S0874-02832013000300017

9. Chauveau A, Tétart P, organizador. Questões para a história do presente. São Paulo: EDUSC; 1999.

10. Aguiar CG, Teixeira MF. Trajetória da secretaria municipal de saúde de Volta Redonda: Análise histórica desde a sua criação até a atualidade [monografia]. Rio de Janeiro (RJ): Fundação Oswaldo Cruz; 2008.

11. Organização do Estágio do Curso de Enfermagem/SOBEU em Saúde Mental; Volta Redonda: Centro de Estudos em Saúde Mental (CESAM); 1997.

12. Neves HG, Lucchese R, Munari DB, Vera I, Santana FR. O processo de formação do enfermeiro em saúde mental para atenção primária em saúde. Rev Rene [Internet]. 2012; [cited 2017 Nov 7]; 13(1):53-63. Available from: $\mathrm{http}: / /$ periodicos.ufc.br/rene/article/view/3768/2982

13. Moraes AEC, Almeida Filho AJ, Santos TCF, Peres MAA, Souza MCF, et al. Implantação da reforma psiquiátrica no município de volta redonda: implicações para a enfermagem. Texto Contexto Enferm (Florianópolis) [Internet]. $2010 \mathrm{Jul} / \mathrm{Sep}$; [cited 2017 Sep 25]; 19(3):526-35. Available from: http://www.scielo.br/pdf/tce/v19n3/a15v19n3.pdf

14. Stastny P. Introducing peer support work in Latin American mental health services. Cad Saúde Colet [Internet]. 2012; [cited 2017 Nov 5]; 20(4):473-81. Available from: http://dx.doi.org/10.1590/S1414462X2012000400011
15. Esperidião E, Silva NS, Caixeta CC, Rodrigues J. A enfermagem Psiquiátrica, a ABEn e o departamento Científico de enfermagem Psiquiátrica e Saúde mental: avanços e desafios. Rev Bras Enferm [Internet]. 2013 Sep; [cited 2017 Nov 8]; 66(no.esp):171-6. Available from: http://dx.doi.org/10.1590/S0034-71672013000700022

16. Barbosa LR, Pereira LL. The teaching of managerial skills in the perception of teachers of nursing courses. J Nurs UFPE On Line (Recife) [Internet].2014 Mar; [cited 2017 Nov 3]; 8(3):784-6. Available from: https:// periodicos.ufpe.br/revistas/revistaenfermagem/article/view/9740

17. Barbosa LR, Cavalcante MB, Pereira LL. The Challenges on Teaching of Management Competences at Perception Professors' of Nursing. Int $J$ HealSci Res [Internet]. 2016 Jan; [cited 2017 Nov 7]; 6(1):270-7. Available from: http://www.ijhsr.org/IJHSR_Vol.6_Issue.1_Jan2016/40.pdf

18. Sousa YG, Medeiros SM, Lira ALB, Fernandes IK, Feijão AR, Chaves AEP, et al. Care Technology Used by Nurses in the Mental Health Services: Integrative Review. Int Arch Med [Internet]. 2016; [cited 2017 Nov 7]; 9(196):1-9. Available from: http://imed.pub/ojs/index.php/iam/ article/view/1693

19. Öster C, Bäckström S, Lantz I. 'Psychiatric patients' perspectives of student involvement in their care. BMC Med Educ [Internet]. 2015 [cited 2017 Nov 7]; 15:69. Available from: https://doi.org/10.1186/ s12909-015-0352-z

20. Fokuo JK, Goldrick V, Rossetti J, Wahlstrom C, Kundert C, Larson J, et al. Decreasing the Stigmaof Mental Illness Through a Student-Nurse Mentoring Program: A Qualitative Study. Community Ment Health J [Internet]. 2017 Apr; [cited 2017 Nov 4]; 53(3):257-65. Available from: https://doi.org/10.1007/s10597-016-0016-4

21. Rodrigues RM, Conterno SFR, Guedes GC. Formação na graduação em enfermagem e impacto na atuação profissional na perspectiva de egressos. Interf Educ (Paranaíba) [Internet]. 2015; [cited 2017 Nov 5] 6(17):26-43. Available from: https://periodicosonline.uems.br/index. php/interfaces/article/view/744

22. Edward KL, Warelow P, Hemingway S, Hercelinskyj G, Welch A, McAndrew $S$, et al. Motivations of nursing students regarding their educational preparation for mental health nursing in Australia and the United Kingdom: a survey evaluation. BMC Nurs [Internet]. 2015 May; [cited 2017 Nov 8]; 14:29. Available from: https://doi.org/10.1186/s12912-015-0084-8 